\title{
PERANCANGAN SISTEM INFORMASI CATATAN KESEHATAN IBU HAMIL DAN IBU BERSALIN BERBASIS SMS NOTIFIKASI
}

\author{
Noor Latifah \\ Fakultas Teknik, Program Studi Sistem Informasi \\ Universitas Muria Kudus \\ noor.latifah@umk.ac.id
}

\begin{abstract}
The maternal health record is a record that contains the development of the fetus and the pregnant health record as well, this note is very important as a reference when a pregnant woman will give birth so that in addition to this note is given to the patient (pregnant women) midwife and gynecologist place control should also have this health record. Patients also often forget to bring even forget to put or keep this health notebook so forget the date of return control that has been written on the note note. Patients should not forget the date of re-control and not be empty of health record book then made the design of health information system for pregnant mother and mother-based sms notification with the aim can be a reminder of date of control visit for pregnant mother and reminded of date of estimated delivery. Methods of data collection is done by direct observation, interview and literature study. System design using UML modeling language. The result of this research is the design of information system of maternity health record and maternity based on sms notification with purpose as reminder of date of control visit for pregnant mother and reminder of estimated date of labor and assist in better management of maternal and maternal health record.
\end{abstract}

Keywords: pregnancy, maternity, sms, notification, childbirth

\begin{abstract}
Abstrak
Catatan kesehatan ibu hamil merupakan catatan yang berisi mengenai perkembangan janin yang dikandungnya serta catatan kesehatan mengenai ibu hamil juga, catatan ini sangat penting sebagai acuan ketika seorang ibu hamil akan melakukan persalinan sehingga selain catatan ini diberikan kepada pasien(ibu hamil) bidan maupun dokter kandungan tempat kontrol juga harus memiliki catatan kesehatan ini. Pasien juga sering lupa membawa bahkan juga lupa menaruh atau menyimpan buku catatan kesehatan ini sehingga lupa dengan tanggal kembali kontrol yang sudah ditulis dibuku catatan tersebut. Pasien supaya tidak lupa dengan tanggal kembali kontrol dan tidak menjadi kosong buku catatan kesehatannya maka dibuatlah perancangan sistem informasi kesehatan bagi ibu hamil dan ibu bersalin berbasis sms notifikasi dengan tujuan bisa menjadi pengingat akan tanggal kunjungan kontrol bagi ibu hamil dan mengingatkan akan tanggal perkiraan persalinannya. Metode pengumpulan data dilakukan dengan pengamatan secara langsung, wawancara dan studi literatur. Perancangan sistem menggunakan bahasa pemodelan UML. Hasil penelitian ini adalah perancangan sistem informasi catatan kesehatan ibu hamil dan ibu bersalin berbasis sms notifikasi dengan tujuan sebagai pengingat tanggal kunjungan kontrol bagi ibu hamil dan pengingat tanggal perkiraan persalinan serta membantu dalam pengelolaan catatan kesehatan ibu hamil dan ibu bersalin dengan lebih baik.
\end{abstract}

Kata kunci: hamil, bersalin, sms, notifikasi, persalinan 


\section{PENDAHULUAN \\ Latar Belakang}

Kehamilan merupakan hal yang sangat dinantikan oleh seorang wanita setelah melaksanakan pernikahan. Ketika seorang wanita dinyatakan hamil maka perlu diperhatikan mengenai asupan makanan, vitamin, serta kesehatan baik kesehatan ibu dan anak yang dikandungnya. Cara untuk bisa mengetahui terpenuhi atau tidaknya mengenai asupan gizi untuk ibu maupun anak yang dikandungnya salah satunya adalah dengan melakukan kontrol rutin ke bidan maupun dokter kandungan. Kontrol ke bidan maupun dokter kandungan dengan tujuan untuk bisa mengetahui usia janin yang dikandung dan perkembangan kondisi janin apakah perkembangannya sesuai dengan usianya atau tidak, selain itu ibu janin juga bisa melakukan konsultasi mengenai hal-hal yang berkaitan dengan kandungannya. Hasil kontrol akan dicatat dalam buku konsultasi yang harus di bawa setiap kali kontrol untuk melihat perkembangan janin serta kesehatan ibu janin. Kebanyakan dari ibu hamil lupa dengan tanggal kontrol ke bidan maupun ke dokter kandungan sehingga terkadang bisa menyebabkan penanganan yang terlambat jika terjadi perkembangan janin yang tidak sesuai dengan perkembangan standar janin sesuai dengan usia janinya, begitu pula dengan buku catatan konsultasi juga seringkali lupa membawa bahkan lupa tempat menyimpannya.

Catatan kesehatan ibu hamil setiap kali kontrol sangat penting karena akan digunakan untuk acuan ketika ibu hamil akan melakukan persalinan. Dari catatan kesehatan ibu hamil tersebut nantinya akan bisa dipakai untuk melakukan persiapan-persiapan yang harus ada ketika persalinan atau kegiatankegiatan yang wajib dilakukan sebelum dilakukan persalinan seperti misalnya harus mengikuti yoga atau harus diet karbohidrat karena berat janin yang disudah melebihi batas standar usianya diperut maupun digunakan untuk mengambil keputusan bahwa ibu hamil tersebut bisa melakukan persalinan secara normal atau harus dilakukan operasi. Sehingga kontrol kehamilan ke bidan maupun ke dokter sangatlah penting. Supaya tidak lupa dengan jadwal kontrol dibutuhkan bantuan pengingat untuk mengingatkan akan jadwal kontrol sesuai dengan jadwalnya.

Catatan ibu bersalin juga sangat penting karena dalam catatan tersebut terdapat datadata yang nantinya bisa digunakan sebagai acuan ketika seorang ibu hamil anak yang kedua atau selanjutnya, bagaimana keadaan ibu ketika melahirkan dan bagaimana kondisi bayi yang dilahirkan apakah sehat atau butuh penanganan khusus. Catatan ini sangat penting namun kebanyakan para ibu mengabaikan catatan-catatan bahkan lupa menaruh setelah ibu melewati masa persalinan karena dianggap setelah persalinan catatan tersebut sudah tidak penting. Untuk menghindari masalah yang disebabkan karena lupa atau hilangnya catatan kesehatan ibu hamil dan catatan kesehatan ibu besalin dan bayinya maka diperlukan aplikasi bantu untuk dapat menyimpan data-data tersebut dengan baik.

SMS notifikasi merupakan sms yang bertujuan untuk memberikan peringatan secara otomatis mengenai apa yang harus dilakukan sesuai waktu yang sebelumnya sudah ditentukan. Dengan dibuatnya perancangan aplikasi catatan kesehatan ibu hamil dan ibu bersalin beserta bayinnya dengan bantuan pengingat jadwal kontrol ibu hamil nantinya bisa membantu mengingatkan ibu hamil supaya tidak lupa untuk melakukan kontrol kehamilannya baik di bidan maupun dokter.

Dari permasalahan yang sudah diuraikan di atas maka dibuatlah perancangan sistem informasi pencatatan kesehatan ibu hamil dan catatan kesehatan ibu bersalin beserta bayi yang baru lahir dengan bantuan sms notifikasi sebagai pengingat jadwal kontrol selama hamil sampai menjelang persalinan.

\section{Rumusan Masalah}

Bagaimana melakukan analisa dan perancangan sistem informasi catatan kesehatan ibu hamil dan ibu bersalin berbasis sms notifikasi.

\section{Batasan masalah}

Dalam penelitian ini akan dibahas tentang pengelolaan catatan kesehatan ibu hamil dan catatan kesehatan ibu bersalin beserta bayi yang baru dilahirkan serta sms notifikasi yang 
digunakan untuk membantu mengingatkan ibu hamil mengenai jadwal kontrol serta waktu perkiraan persalinan.

\section{METODOLOGI PENELITIAN Metode Pengumpulan Data}

Data diperoleh dengan melakukan studi pustaka yaitu dengan membaca jurnal, buku dan hasil-hasil penelitian yang ada kaitannya dengan catatan kesehatan ibu hamil dan ibu bersalin, selain itu data juga diperoleh dengan mengamati secara langsung dan dengan melakukan wawancara dengan pihak yang terkait.

\section{Analisa Kebutuhan Data}

a. Kebutuhan data.

Kebutuhan data hasil dari analisa untuk aplikasi ini adalah :

1. Data identitas keluarga

2. Data ibu hamil

3. Data catatan kesehatan ibu hamil

4. Data Ibu bersalin

5. Data bayi saat lahir

b. Informasi yang dihasilkan
1. Informasi Kesehatan ibu hamil

2. Informasi kesehatan ibu bersalin

3. Informasi kesehatan bayi saat lahir

\section{Perancangan Sistem}

Setelah dilakukan analisa dan diperoleh data-data serta beberapa informasi yang harus terpenuhi maka langkah selanjutnya adalah membuat perancangan sistemnya dengan menggunakan bahasa pemodelan Unified Modelling System (UML). Dalam bahasa pemodelan UML terdapata beberapa diagram-diagram yang bisa dibuat untuk menggambarkan perancangan sistem diantaranya yaitu diagram sistem use case, diagram kelas dan diagram aktifitas.

\section{HASIL DAN PEMBAHASAN Diagram Use Case}

Proses apa saja yang akan dilakukan oleh aktor yang terlibat dalam sistem bisa dilihat dalam diagram sisteem use case, dimana aktornya terdiri dari pasien dan petugas kesehatan dengan berbagai proses yang mereka lewati.

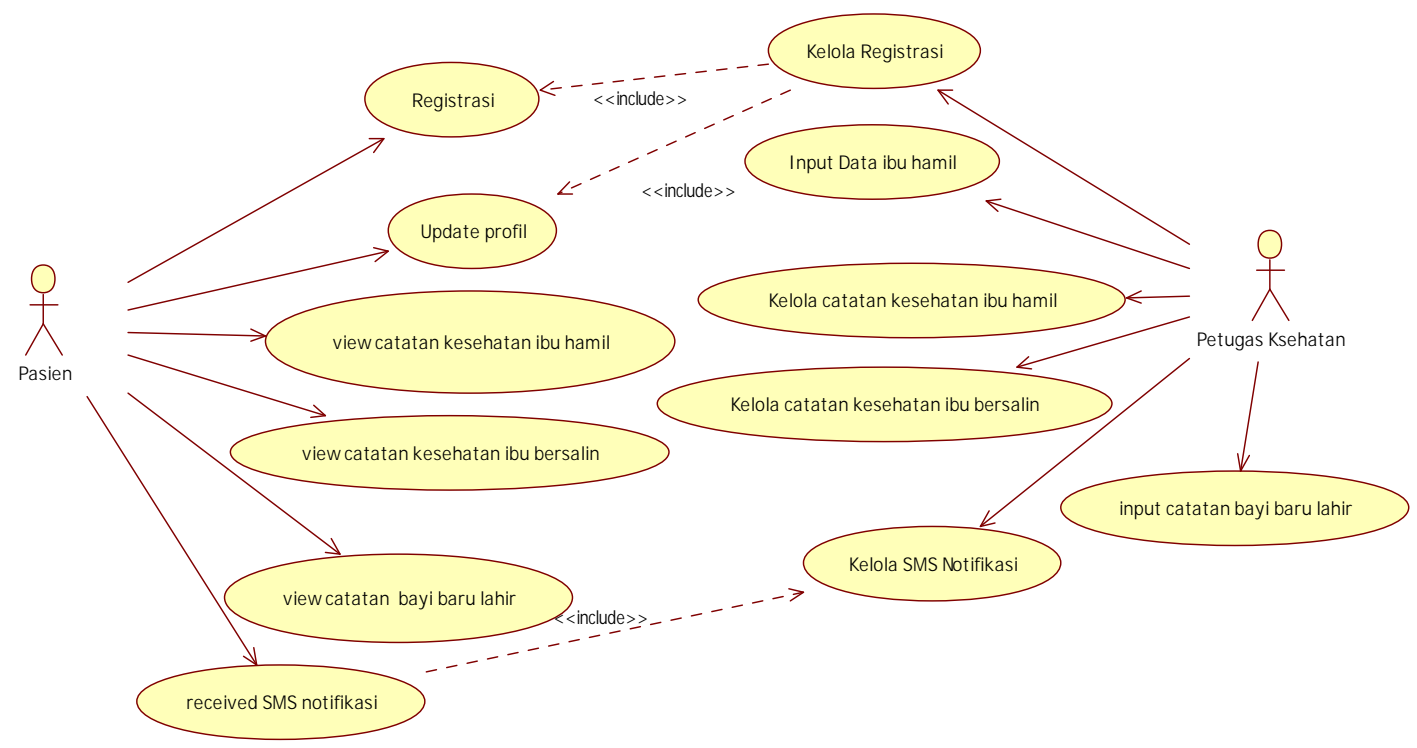

Gambar 1. Diagram Simtem Use Case Sistem Informasi Catatan kesehatan ibu hamil dan ibu bersalin berbasis SMS Notifikasi

\section{Diagram Kelas}

Diagram kelas menggambarkan hubungan antar kelas-kelas yang dibangun dan saling terkait. Dalam Sistem Informasi Catatan kesehatan ibu hamil dan ibu bersalin berbasis SMS Notifikasi terdapat 14 kelas. 


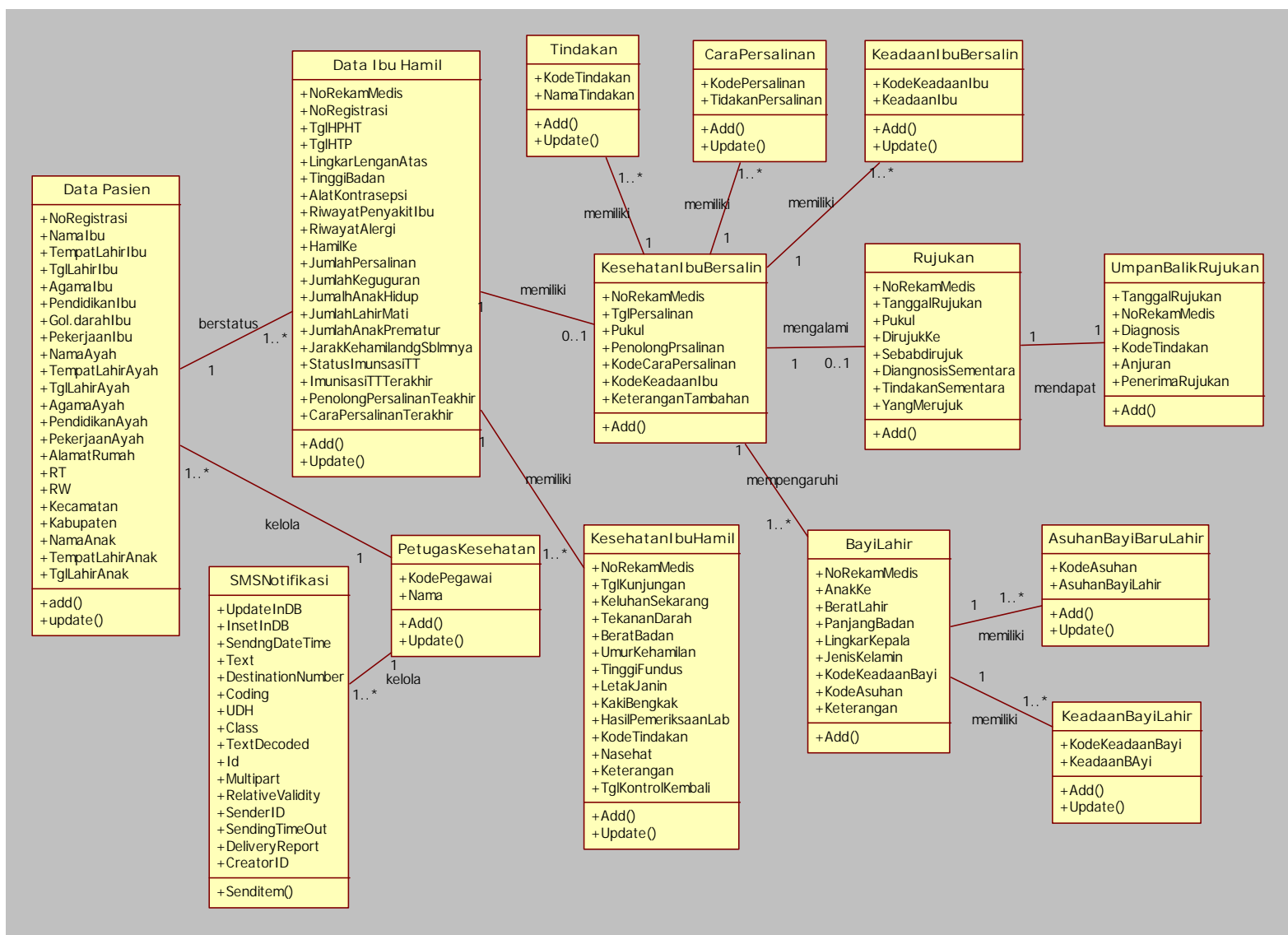

Gambar 2. Diagram Kelas Sistem Informasi Catatan kesehatan ibu hamil dan ibu bersalin berbasis SMS Notifikasi

\section{Diagram Aktifitas}

Diagram aktifitas berikut akan menggambarkan aktifitas-aktifitas yang berlangsung dalam suatu proses. Diagram aktifitas dalam Sistem Informasi Catatan kesehatan ibu hamil dan ibu bersalin berbasis SMS Notifikasi terdiri dari diagram aktifitas registrasi pasien, diagram aktifitas catatan kesehatan ibu hamil dan ibu bersalin serta diagram aktifitas catatan kesehatan bayi baru lahir.

\section{Diagram aktifitas Registrasi pasien}

Diagram aktifitas registrasi pasien, pasien melakukan registrasi yang kemudian petugas kesehatan akan melakukan input data pasien jika pasien hamil maka akan diinputkan data ibu hamil namun jika pasien bersalin yang sebelumnya tidak periksa kehamilan ditempat tersebut makan akan dinputkan catatan kesehatan ibu bersalin, pasien juga dapat melakukan update profil sendiri melalui web.

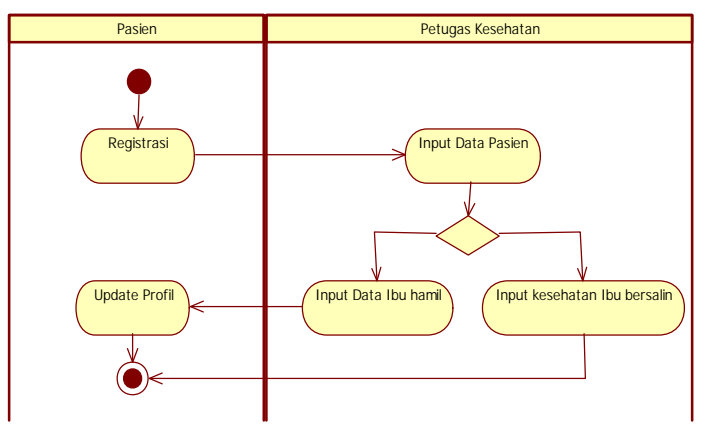

Gambar 3. Diagram Aktifitas Registrasi Pasien Sistem Informasi Catatan kesehatan ibu hamil dan ibu bersalin berbasis SMS Notifikasi

\section{Diagram Aktifitas Catatan Kesehatan Ibu Hamil dan Ibu Bersalin}

Dalam diagram aktifitas ini menggambarkan aktifitas yang dilakukan oleh petugas kesehatan yang dimulai dengan melakukan input data ibu hamil, jika pasien melakukan registrasi (kunjungan kontrol) maka akan diinputkan oleh petugas data-data catatan kesehatan ibu hamil termasuk 
memasukkan tanggal kembali berkunjung untuk kontrol yang nantinya sebelum tanggal tersebut pasien akan mendapatkan sms notifikaksi untuk mengingatkan akan jadwal kontrolnya, jika tidak melakukan kunjungan maka pasien masih tetap melihat catatan kesehatan kehamilannya. Petugas kesehatan melakukan inputan catatan kesehatan ibu bersalin, menginputkan keadaan ibu bersalin apakah perlu dibuatkan rujukan jika tidak perlu dirujuk maka akan diinputkan oleh petugas mengenai tindakan dan cara bersalin sedangkan pasien nantinya bisa melihat catatan kesehatan bersalinnya.

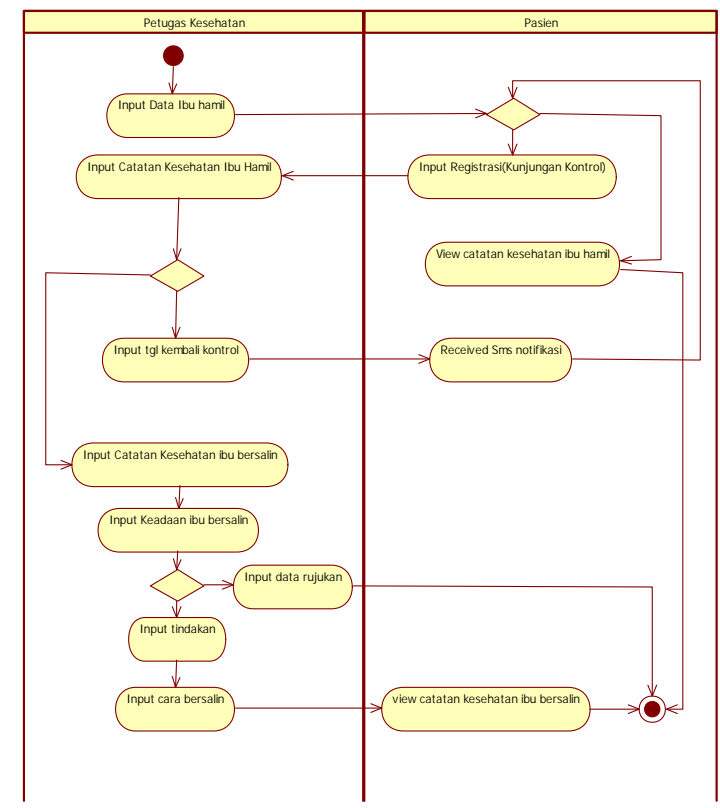

Gambar 4. Diagram Aktifitas Catatan Kesehatan Ibu Hamil dan Ibu Bersalin Sistem Informasi Catatan kesehatan ibu hamil dan ibu bersalin berbasis SMS Notifikasi

\section{Diagram Aktifitas Catatan Kesehatan Bayi Baru Lahir}

Dalam diagram aktifitas catatan kesehatan bayi baru lahir dimulai dengan petugas kesehatan melakukan input data bayi lahir, input asuhan bayi, dan input keadaan bayi apakah bayi memerlukan rujukan apa tidak, jika memerlukan rujukan maka akan diinputkan data rujukan.

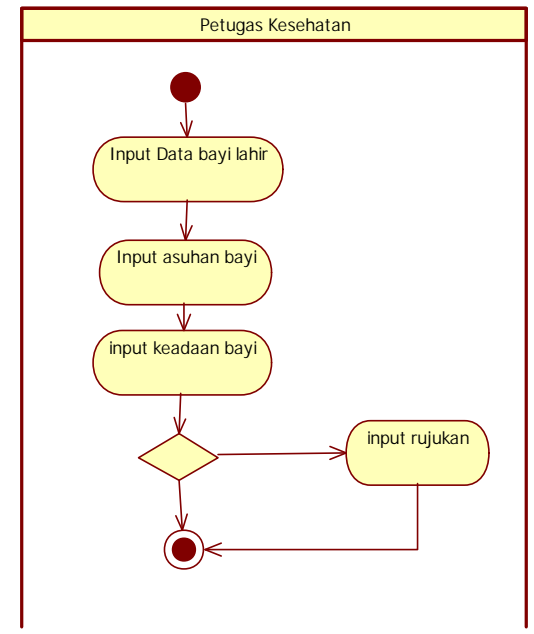

Gambar 5. Diagram Aktifitas Catatan Kesehatan Bayi Baru Lahir Sistem Informasi Catatan kesehatan ibu hamil dan ibu bersalin berbasis SMS Notifikasi

\section{SIMPULAN}

Hasil dari analisa dan pembahasan yaitu didapatkan suatu perancangan Sistem Informasi Catatan kesehatan ibu hamil dan ibu bersalin berbasis SMS Notifikasi dengan perancangan ini diharapkan bisa segera diimplementasikan aplikasinya supaya bisa membantu ibu hamil dalam hal mengingatkan untuk jadwal kontrol kehamilannya dengan menggunakan sms notifikasi, serta bisa mengantisipasi jika ibu hamil ataupun ibu bersalin lupa membawa buku catatan kesehatannya karena sudah ter-backup dalam aplikasi yang dirancang ini sehingga bisa tetap diketahui rekam medis perkembangan janin untuk setiap kali kontrol yang telah dilakukan.

\section{DAFTAR PUSTAKA}

Julia Dian Pratiwi dan Nur Rokhman, "Pengembangan Input Sistem Informasi Ksehatan Ibu dan Anak Berbasis Web di RSKIA Bhakti Ibu Yogyakarta," Jurnal Kesehatan Vokasional, vol. 1, no. 2, pp. 81-86, April 2017.

Hamzah and Sugeng Winardi, "Sistem Informasi Layanan SMS Gateway Bagi Bidan Dalam Program Pemantauan Kesehatan Ibu dan Anak (PWS KIA) di Kabupaten Bantul Provinsi Daerah Istimewa Yogyakarta", Infotel, vol. 7, no. 1, pp. 29-37, Mei 2015. 
"Pengembangan Sistem Informasi Pelayanan Kesehatan Ibu Dan Bayi Untuk Mendukung Evaluasi Program Kesehatan Ibu Dan Anak (KIA) Di Puskesmas Kabupaten Lamongan," Univeristas Diponegoro, Semarang, Thesis 2008.

Sholiq, Pemodelan Sistem Informasi Berorientasi Objek Dengan UML.: Graha IImu, 2006.

Suci Rahma Dani Rahman, "Perancangan Aplikasi Pelayanan Informasi Kesehatan Ibu Dan Anak Berbasis Data Center Studi Kasus Puskesmas Kota Makassar," in Seminar Nasional Teknologi Informasi dan Multimedia 2015, Yogyakarta, 2015, pp. 561-565. 